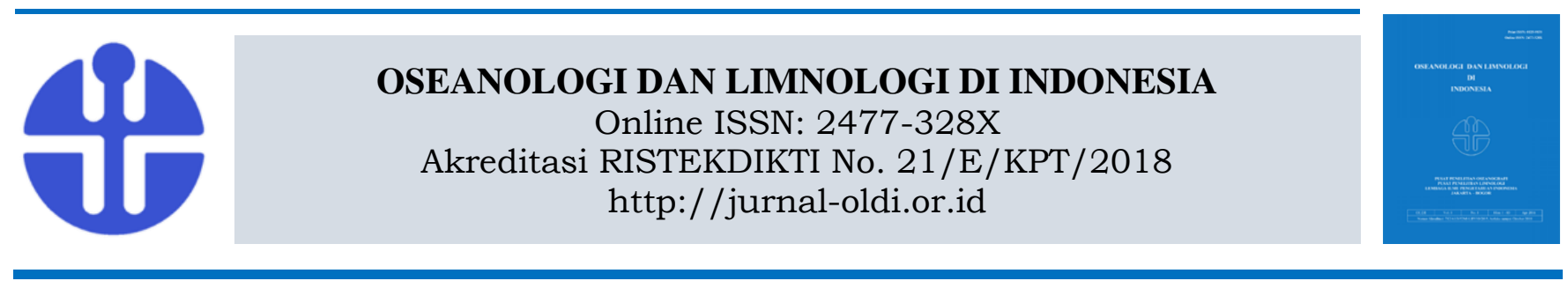

\title{
Faktor Hidro-Oseanografi Terhadap Distribusi Air Tawar Bersuhu Rendah Dekat Pantai Sekitar Lokasi Keluaran Air Tanah Lepas Pantai (KALP) di Perairan Lombok Utara, Indonesia
}

\author{
Ulung Jantama Wisha ${ }^{1 *}$ dan Gunardi Kusumah ${ }^{1}$ \\ ${ }^{1}$ Loka Riset Sumber Daya dan Kerentanan Pesisir - KKP, Jl. Raya Padang-Painan KM. 16, Bungus, Padang, \\ Sumatera Barat - Indonesia 25245 \\ *Email: ulungjantama@gmail.com
}

Submitted 18 July 2017. Reviewed 09 March 2018. Accepted 11 July 2018.

DOI: 10.14203/oldi.2019.v4i3.157

\begin{abstract}
Abstrak
Pantai Utara Lombok memiliki banyak sumberdaya seperti Keluaran Air Tanah Lepas Pantai (KALP). Keluaran air tanah terbesar terdapat di Pantai Krakas. Keluaran air tanah yang dingin mungkin memicu ketidakseimbangan lingkungan disekitarnya (pendinginan lokal). Tujuan dari penelitian ini adalah untuk mengetahui pengaruh dari faktor fisika yang mendukung distribusi keluaran air tanah dingin. Kegiatan survei lapangan dilakukan pada tanggal 23-26 Maret 2016. Flow model dan analisis statistik digunakan untuk mengetahui pola transport dari anomali suhu. Secara vertikal, pergerakan arus laut mengikuti kaidah spiral Ekman yang mempengaruhi distribusi vertikal dari air tanah. Kecepatan arus pada kondisi menuju pasang berkisar antara 0-0,15 cm/detik, dominan arah arusnya menuju ke barat daya. Pada saat menuju surut kecepatan arus berkisar antara 0-0,32 cm/detik, dominan arah arusnya menuju ke timur laut. Fluktuasi suhu mengikuti perubahan elevasi muka air di lokasi KALP dimana nilai korelasi sebesar $63 \%$.
\end{abstract}

Kata kunci: Hidro-oseanografi, suhu perairan pantai, keluaran air tanah lepas pantai, Pantai Krakas

\begin{abstract}
The Influence of Hydro-Oceanography Factors on the Distribution of Near-shore LowTemperature Freshwater around Submarine Groundwater Discharge (SGD) Area in the North Lombok Waters, Indonesia. North Lombok coast has lot of resources of Submarine Groundwater Discharge (SGD). The biggest discharge appeared in the Krakas Beach where cold groundwater discharge many spots might trigger anomalies in the ambient water temperature. This study was aimed to determine the distribution of the cold groundwater discharge. A field survey was conducted on March 23th - 26th, 2016. Flow model and statistical analysis were employed to determine the transport pattern of temperature anomalies. Vertically, the current direction is in accordance with Ekman spiral that triggers the vertical cold groundwater distribution. The current speed during the displacement toward high tide ranges $0-0.15 \mathrm{~cm} / \mathrm{s}$ which predominantly moves south-westward. During low tide, tidal current was predominantly northeastward moving at $0-0.3 \mathrm{~cm} / \mathrm{s}$. Temperature variation around the SGD spot fluctuated following sea surface surface elevation dynamics in which these two parameters has a correlation value of $63 \%$.
\end{abstract}

Keywords: Hydro-oceanography, near-shore temperature, submarine groundwater discharge, Krakas Beach 


\section{Pendahuluan}

Pulau Lombok memiliki banyak sumber daya pesisir seperti pantai yang indah, keanekaragaman biota, dan ketersediaan air, yang mendukung wisata bahari di beberapa daerah. Karena keberadaan Gunung Rinjani, air dingin terdistribusikan dari tempat yang lebih tinggi ke pantai melalui rembesan. Proses ini disebut Keluaran Air Tanah Lepas Pantai (KALP).

Keluaran air tanah lepas pantai (KALP) merupakan sebuah fenomena rembesan yang terjadi di dekat pantai (near-shore seepage), seepage di dasar laut, dan sumber air tawar bawah laut (Lubis et al., 2011). Kemunculan KALP disebabkan oleh perbedaan gradien hidrolik dari permukaan air tanah antara suatu area dan area lain disekitarnya. Menurut Moore (2010) sumber air merupakan manifestasi air tanah yang keluar secara alami baik di permukaan tanah maupun di permukaan badan air dekat pantai.

Secara umum, terjadinya KALP dipengaruhi oleh beberapa parameter seperti iklim, kondisi geologi, topografi, tipe tanah \& batuan, permeabilitas batuan, gradien tekanan air permukaan dan pasang surut di daerah intertidal (Thompson et al., 2007).

KALP di Pulau Lombok yang telah teridentifikasi berada di utara dan timur (Bakti et al., 2012). Ada beberapa titik keluaran air tanah dekat pantai di Kecamatan Lombok Utara. Yang terbesar terletak disekitar 100-250 m dari Pantai Krakas. Keluaran air tanah dilokasi tersebut telah dimanfaatkan oleh masyarakat lokal dengan menghubungkan sumber air tawar dengan pipa panjang, sehingga orang-orang dapat menggunakan air tawar dengan mudah (Gambar 1). Saat ini, pipa tersebut tidak lagi digunakan. Selain itu, beberapa titik KALP juga teridentifikasi di sekitar Pantai Krakas dan sekitarnya (Lestiana et al., 2017).

KALP di Pantai Krakas membawa suhu rendah. Kondisi ini dapat mempengaruhi lingkungan di daerah sekitarnya. Semburan air dingin dari KALP terdistribusikan oleh angin, pasang surut, dan arus. Arus pasang surut memiliki peran penting dalam distribusi keluaran air dingin di sepanjang pantai dimana fluktuasi suhu air mungkin dipengaruhi oleh perubahan elevasi permukaan air (kondisi pasang surut) (Boehm et al., 2002).

Posisi KALP di Pantai Krakas berada didaerah intertidal yang masih dipengaruhi oleh aliran arus sejajar pantai yang sangat dinamis. Kondisi tersebut dengan mudah memicu pengangkutan air tanah dengan suhu rendah ke lingkungan disekitarnya (Johan et al., 2018). Hal 146 ini dapat mempengaruhi ketidakseimbangan lingkungan dan masalah siklus biogeokimia.



Gambar 1. Kondisi keluaran air tanah di Pantai Krakas

Figure 1. The outlet of SGD spot in the Krakas Village

Studi tentang KALP telah dikembangkan sejak tahun 2000 dalam bentuk jurnal dan peta KALP. Sementara itu, data terkait KALP di Indonesia belum tercatat di peta tersebut karena fenomena ini sangat kurang diteliti. Sebenarnya, Indonesia memiliki banyak potensi KALP. Beberapa penelitian sebelumnya dilakukan oleh Bakti et al., (2012) dan Lubis et al., (2011) yang mendefinisikan KALP secara geologis dan lokasilokasi KALP di Indonesia. Maka, sebuah studi untuk mengetahui distribusi keluaran air tanah karena kondisi hidro-oseanografi di Lombok Utara sangat penting untuk dilakukan. Penelitian ini bertujuan untuk mengetahui pengaruh faktor fisik perairan yang mempengaruhi distribusi air tawar dengan suhu rendah di sekitar area KALP.

\section{Metodologi}

\section{Waktu survei dan lokasi penelitian}

Penelitian ini dilakukan pada 26- 29 Maret 2016 di Pantai Krakas, Kecamatan Lombok Utara. Lokasi ini berbatasan langsung dengan Selat Lombok yang merupakan salah satu gerbang Arus Lintas Indonesia, yang memiliki peran dalam pengaruhnya di lingkungan perairan.

Keberadaan gunung Rinjani memicu air tanah dengan suhu rendah mengalir melalui rembesan tanah. Rembesan tersebut muncul di area bertekanan rendah seperti pantai dan dekat pantai. Banyak keluaran air tanah yang telah teridentifikasi di Pantai Krakas (Bakti et al., 2012). Dalam studi ini, akan diobservasi dua pusat KALP terbesar (Gambar 2). 


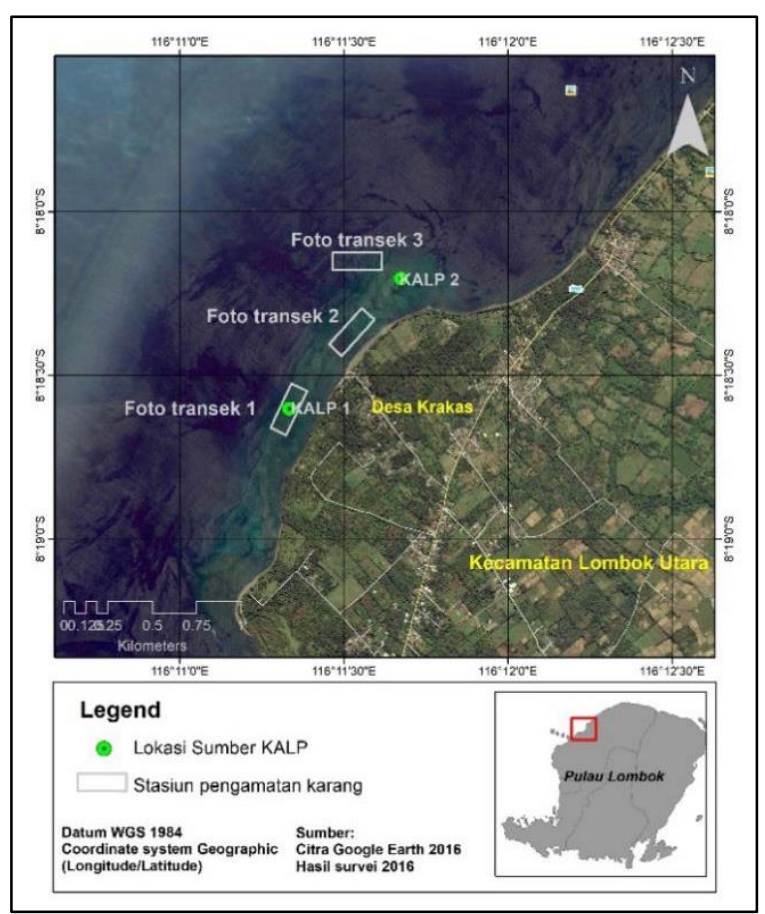

Gambar 2. Peta Lokasi Penelitian

Figure 2. Map of the study area

\section{Materi penelitian}

Data primer terdiri dari pasang surut, suhu, dan arus yang diukur langsung di lapangan. Data pasang surut dan temperatur diperoleh dengan menggunakan $\mathrm{HOBO}$-ware yang pasang selama 1 bulan di titik KALP. ADCP-Nortek (Acoustic Doppler Current Profiler) digunakan untuk merekam data arus selama dua hari pengukuran. ADCP dapat merekam beberapa data fisik seperti suhu, dan arus, data pasang surut. Sedangkan, data sekunder terdiri dari data batimetri dan koordinat garis pantai diambil dari laman web GEBCO (General Bathymetry Chart of The

Ocean)(https://www.gebco.net/data_and_products /gridded_bathymetry_data/).

\section{Analisis hidrodinamika}

Sirkulasi air disimulasikan berdasarkan model hidrodinamika untuk menentukan pola distribusi suhu air di permukaan yang dimodelkan selama 15 hari untuk mewakili kondisi pasang surut purnama dan perbani. Flow model digunakan untuk membangun model numerik yang ditunjukkan dalam bentuk simulasi dua dimensi (Mehdiabadi et al., 2015; Warren \& Bach, 1992). Data batimetri dan digitasi garis pantai digunakan sebagai input model. Data elevasi permukaan air diperoleh melaui perangkat lunak NAOtide dalam bentuk data deret waktu. Susunan model hidrodinamika ditunjukkan pada Tabel 1 . Data angin tidak digunakan untuk mensimulasikan model hidrodinamika karena model area tidak terlalu luas dan dekat pantai (perairan dangkal) dimana pengaruh angin sangat kecil. Data pasang surut juga digunakan dalam validasi model hidrodinamika menggunakan rumus RMSE (Root Mean Square Error) (Wisha et al., 2016) sebagai berikut:

$$
R M S E=\sqrt{\frac{1}{N} \sum_{i=1}^{N}\left(x_{i}-y_{i}\right)^{2}}
$$

dimana :

$\mathrm{N}=$ Jumlah data

$x_{i}=$ Hasil model

$y_{i}=$ Data lapangan

Tabel 1. Pengaturan model hidrodinamika

Table 1. Set-up for hydrodynamic model

\begin{tabular}{|c|c|}
\hline Parameter & Implemented in simulation \\
\hline Simulation time & $\begin{array}{l}\text { Number of time step }=350 \\
\text { Time step interval }=600 \text { second } \\
\text { Start and stop simulation date }=5 / 03 / 201624.00-5 / 05 / 201600.50\end{array}$ \\
\hline Mesh boundary & $\begin{array}{l}\text { Bathymetry = GEBCO bathymetry data } \\
\text { Coastline = Google Eye Image digitation }\end{array}$ \\
\hline Flood and Dry & $\begin{array}{l}\text { Drying depth }=0.005 \mathrm{~m} \\
\text { Flooding depth }=0.05 \mathrm{~m} \\
\text { Wetting depth }=0.1 \mathrm{~m}\end{array}$ \\
\hline Boundary condition & $\begin{array}{l}\text { Tide forecasting with coordinates: } \\
\text { 1. Longitude: } 115.98290 \mathrm{E} \text {; } \\
\text { Latitude: }-8.3783 \mathrm{~S} \\
\text { 2. Longitude: } 115.96072 \mathrm{E} \text {; } \\
\text { Latitude: }-8.2476 \mathrm{~S} \\
\text { 3. Longitude: } 116.12450 \mathrm{E} \text {; } \\
\text { Latitude: }-8.0931 \mathrm{~S} \\
\text { 4. Longitude: } 116.30377 \mathrm{E} \text {; }\end{array}$ \\
\hline
\end{tabular}




\section{Hasil}

\section{Profil arus laut di sekitar area KALP}

Scatter plot arus (Gambar 3) menunjukkan bahwa setiap lapisan kolom air memiliki arah arus yang sama. Arus sejajar pantai relatif bergerak ke arah timur laut dan utara dengan kecepatan stabil pada lapisan 7,5 $\mathrm{m}$ dan 5,5 m. Pada kedalaman 3,5$1,5 \mathrm{~m}$, arah arus dominan bergerak ke timur laut dan barat daya. Kecepatan meningkat secara signifikan karena pengaruh pasang surut dan gelombang yang memicu fluktuasi perpindahan massa air.

Gambar 4 menunjukkan pergerakan arus vertikal yang cukup stabil. Semakin dekat ke dasar, arus relatif lebih lemah dan lebih pasif daripada di permukaan. Namun demikian, di lapisan atas, gerakan menjadi lebih acak karena penurunan densitas dan interaksi angin-pasang surut. Menurut Wisha et al., (2015) angin, pasang surut, densitas, dan tegangan geser di dasar adalah faktor utama yang mengendalikan pergerakan arus secara vertikal dan horizontal.

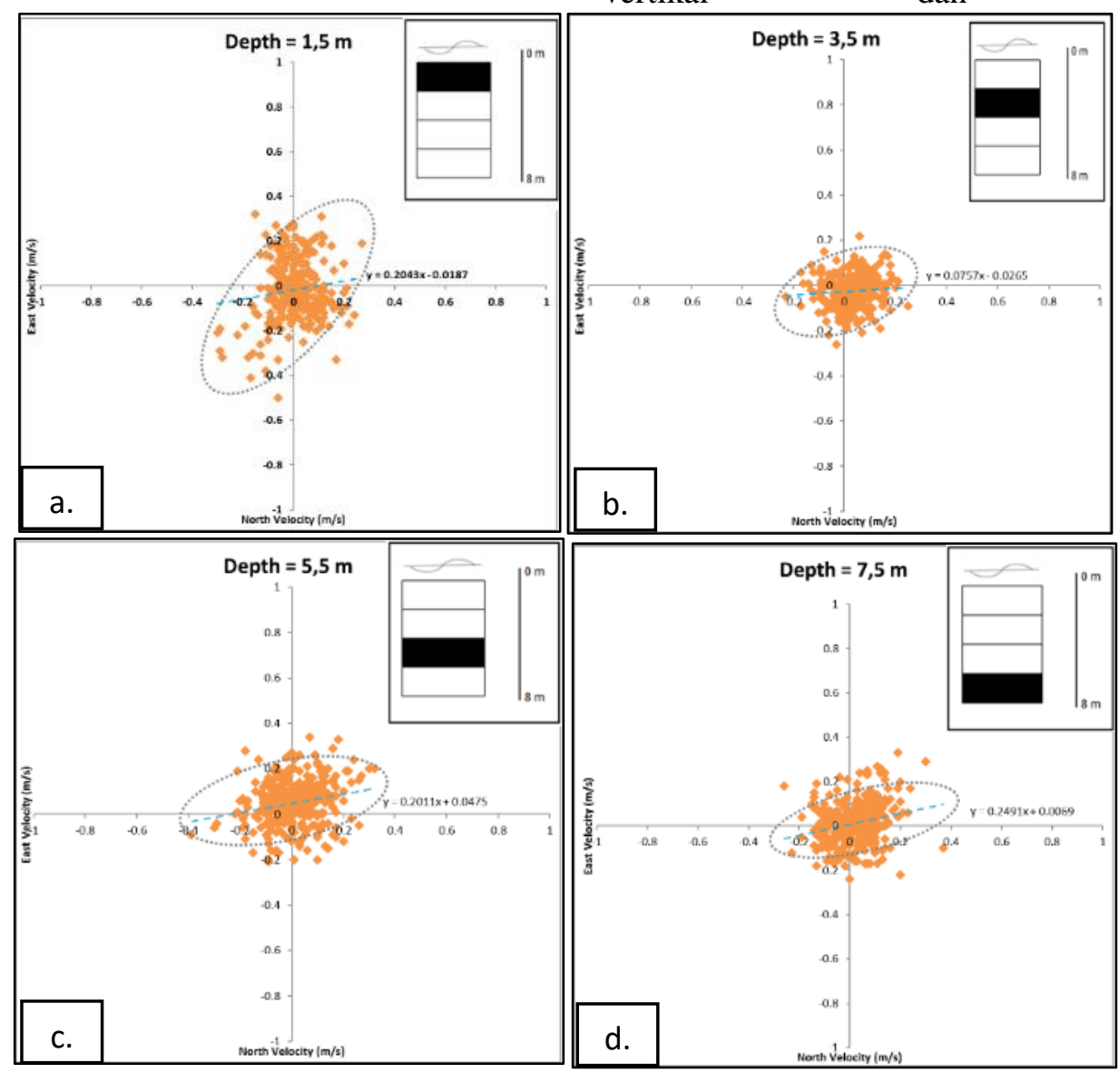

Gambar 3. Scatter plot arus laut di titik KALP; a. profil arus di kedalaman 1,5 meter dari permukaan; b. profil arus di kedalaman 3,5 meter dari permukaan; c. profil arus di kedalaman 5,5 meter dari permukaan; d. profil arus di kedalaman 7,5 meter dari permukaan

Figure 3. Scatter plot of sea current in the SGD spot; a. the current profile in the depth of 1.5 meters from the surface; b. the current profile in the depth of 3.5 meters from the surface; c. the current profile in the depth of 5.5 meters from the surface; $d$. the current profile in depth of 7.5 meter from the surface 
Oseanologi dan Limnologi di Indonesia 2019 4(3): 145-154



Gambar 4. Profil vertikal arus laut di titik KALP; a. Profil vertikal arus zonal; b. Profil vertikal arus meridional; c. Profil vertikal arus ke permukaan

Figure 4. Vertical profile of sea current in the SGD spot; a. Eastward direction; b. Northward direction; c. Upward direction

\section{Analisis pasang surut di area KALP}

Tabel 2 menunjukkan konstituen harmonik pasang surut dihitung menggunakan perangkat lunak ERGtide. Nilai bilangan Formzahl 0,87, yang diperoleh dari perbandingan nilai komponen diurnal dan semidiurnal dari K1, O1, M2, dan S2. Nilai tersebut mewakili tipe pasang surut dari area KALP (campuran condong harian ganda). Menurut Oktavia et al., (2011), perbandingan antara amplitudo komponen utama harian tunggal dan ganda mendefinisikan tipe pasang surut air laut.

Selain tipe pasang surut, analisis Indian Spring Low Water (ISLW) juga menghasilkan elevasi penting pasang surut seperti MSL (ratarata muka air) mencapai $1288,38 \mathrm{~cm}$, MHWS (rata-rata muka air tinggi tertinggi) mencapai $75,38 \mathrm{~cm}$ dari tingkat MSL, HWS (muka air tinggi tertinggi) mencapai $96,76 \mathrm{~cm}$ dari level MSL, MHWL (rata-rata muka air tertinggi) mencapai 38,81 cm dari level MSL, MLWL (rata-rata muka air terendah) mencapai $-38,59 \mathrm{~cm}$ dari level MSL, MLWS (rata-rata muka air rendah terendah) mencapai $-79,56 \mathrm{~cm}$ dari tingkat MSL, dan LWS (muka air rendah terendah) mencapai $-100,98 \mathrm{~cm}$ dari tingkat MSL (Gambar

$5)$.

Tabel 2. Konstituen pasang surut di lokasi KALP

Table 2. Tidal constituent values of SGD spot

\begin{tabular}{ccc}
\hline Constituent & $\begin{array}{c}\text { Amplitude } \\
(\mathrm{cm})\end{array}$ & Phase delay $\left({ }^{\circ}\right)$ \\
\hline M2 & 29.65 & 192.80 \\
S2 & 14.56 & -72.07 \\
N2 & 6.98 & 211.95 \\
K2 & 1.71 & 7.30 \\
K1 & 32.82 & 200.94 \\
O1 & 18.09 & 239.62 \\
P1 & 10.58 & 48.75 \\
M4 & 0.58 & 217.34 \\
MS4 & 0.30 & 20.66 \\
S0 & 1288.38 & \\
\hline Formzahl & 0.87 & Mixed tide prevailing semidiurnal \\
\hline
\end{tabular}




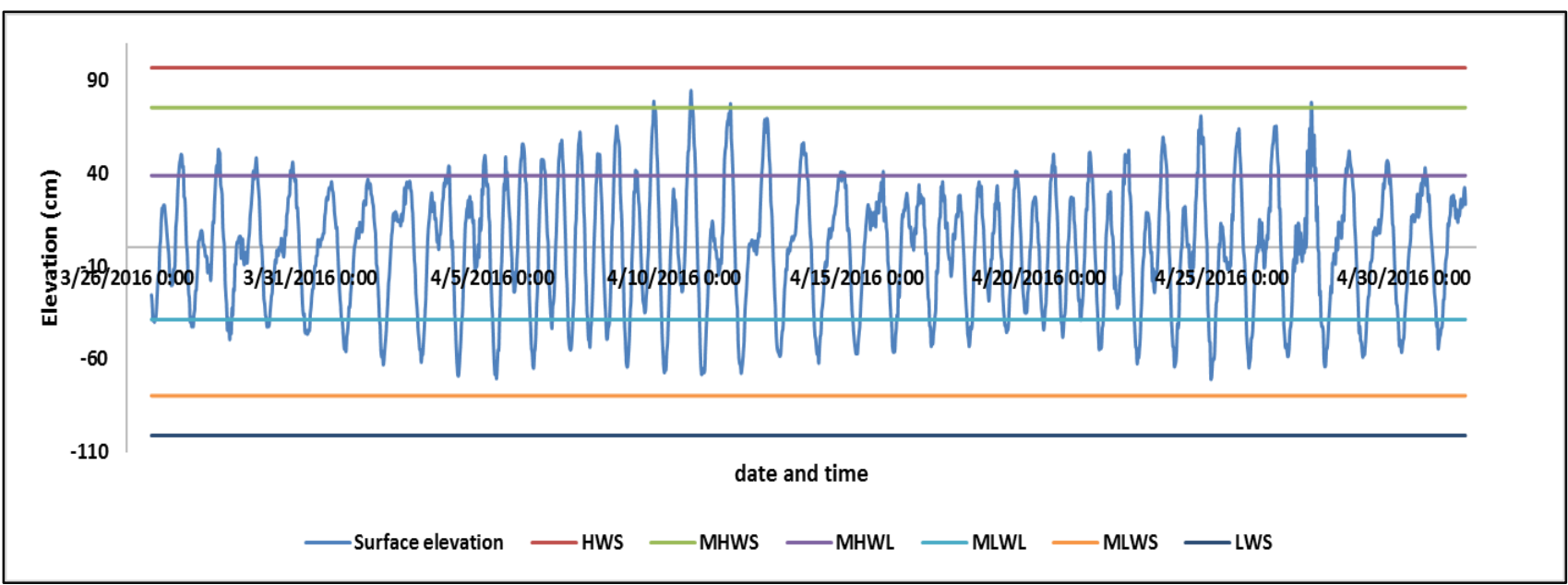

Gambar 5. Elevasi penting pasang surut yang diprediksi berdasarkan analisis Indian Spring Low Water Figure 5. The main tidal elevation as predicted by Indian Spring Low Water analysis

\section{Verifikasi dan hasil model hidrodinamika}

Sebelum diaplikasikan, hasil model harus divalidasi dengan membandingkan hasil model dan data pengukuran lapangan (Gambar 6) dimana fluktuasi elevasi permukaan memiliki fase yang sama antara hasil model dan pengukuran lapangan. Nilai RMSE mencapai 4,37\%.

Pada waktu perpindahan surut menuju pasang, gerakan air relatif lebih cepat daripada posisi permukaan laut lainnya. Kecepatan arus berkisar $0-0,3 \mathrm{~cm} /$ detik dimana arahnya dominan bergerak ke barat dan barat daya (Gambar 7). Sementara pada waktu perpindahan dari pasang menuju surut, kecepatan arus berkisar 0-0,15 $\mathrm{cm} /$ detik dimana arahnya sebagian besar bergerak ke timur dan timur laut (Gambar 8). Air tanah yang muncul dengan cepat bercampur dengan air garam sebelum terdistribusi oleh arus saat pasang dan surut.

Berdasarkan penelitian sebelumnya oleh Rachmayani et al., (2006), kecepatan arus pasang surut di Lombok Utara berkisar 0-0,5 cm/detik selama pasang tinggi. Penelitian terkait lainnya oleh Ningsih et al., (2018) melaporkan bahwa pasang surut di Selat Lombok Utara adalah siklus semidiurnal dan amplitudo arus pasang surut berkisar antara $20-50 \mathrm{~cm} /$ detik. Hal ini dapat mempengaruhi profil arus di pesisir Lombok Utara.

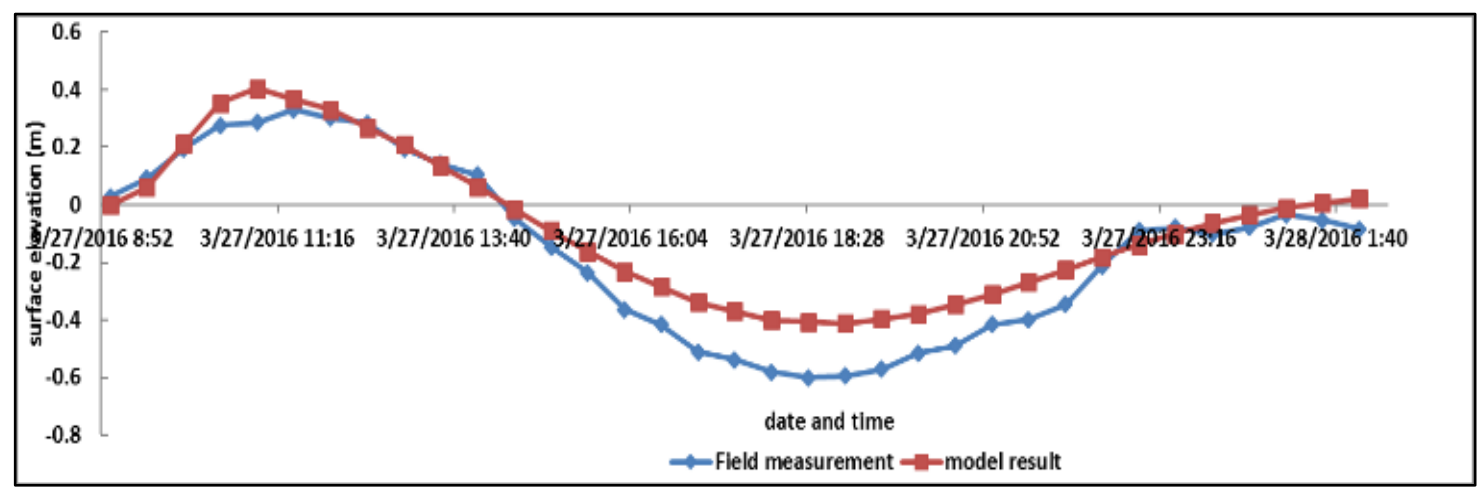

Gambar 6. Validasi hasil model menggunakan data elevasi permukaan

Figure 6. Model validation using surface elevation data from field observation 
Oseanologi dan Limnologi di Indonesia 2019 4(3): 145-154



Gambar 7. Pola arus pasang surut pada kondisi menuju pasang

Figure 7. Tidal current pattern at sea level towards high tidal phase around Krakas Village

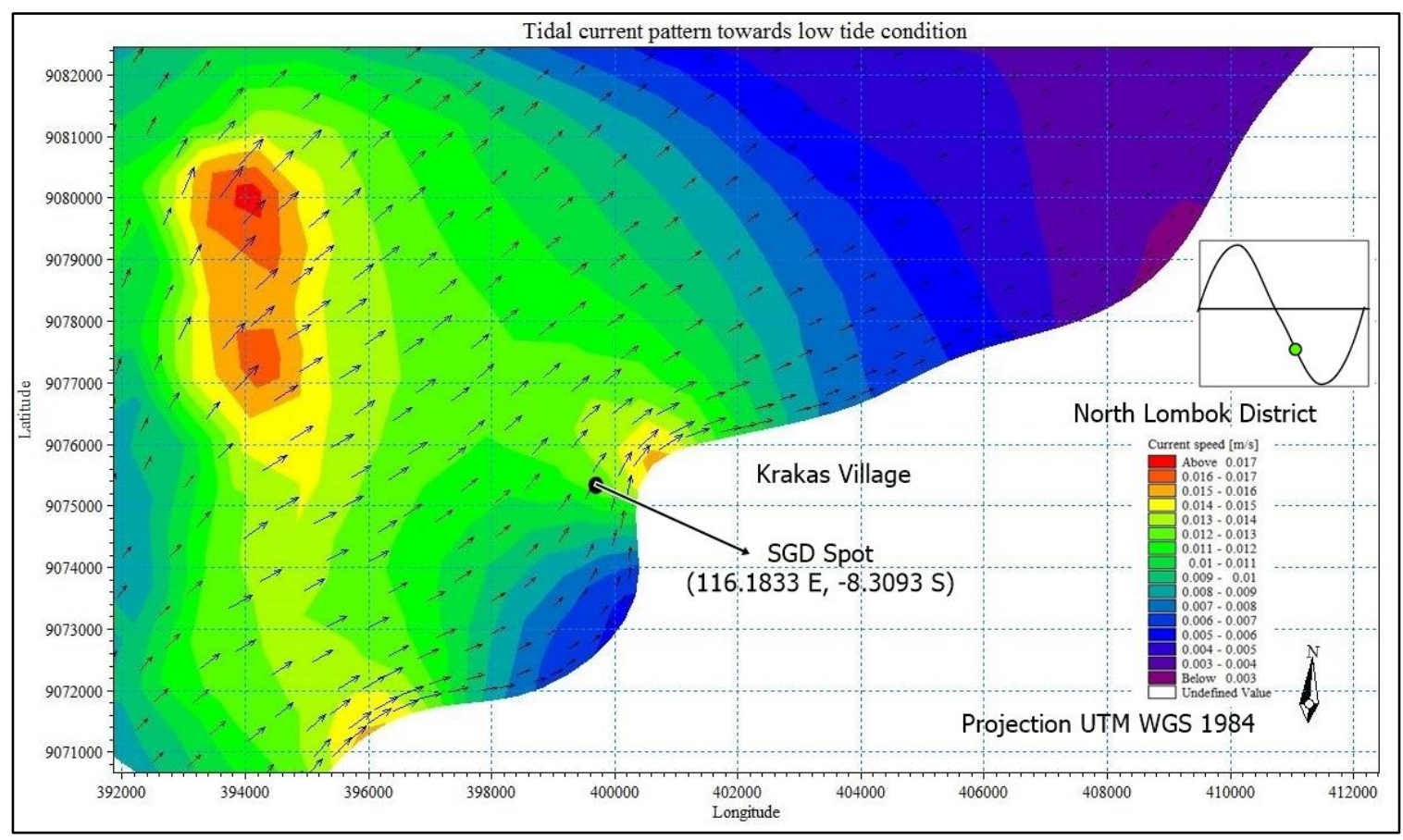

Gambar 8. Pola arus pasang surut pada kondisi menuju surut

Figure 8. Tidal current pattern at sea level towards low tide phase around Krakas Village

\section{Interaksi fluktuasi suhu dengan pasang surut}

Selama 30 hari pengukuran HOBO, suhu berkisar $25,50-29,5{ }^{\circ} \mathrm{C}$ dan tunggang pasang surut mencapai 1,6 m (Gambar 9). Fluktuasi suhu sebanding dengan elevasi permukaan yang mencapai $29^{\circ} \mathrm{C}$ pada kondisi pasang surut purnama dan $27,5^{\circ} \mathrm{C}$ pada kondisi pasang surut perbani.

Penilaian regresi linier juga dilakukan dengan membandingkan data suhu dan elevasi permukaan. Dalam hal ini, suhu menjadi variabel terikat, sementara, elevasi permukaan menjadi variabel bebas. Nilai $R$-square mencapai 0,63 mendefinisikan kemampuan variabel bebas (elevasi permukaan) untuk menjelaskan variabel terikat (suhu) sebesar 63\%. Hal ini juga menunjukkan bahwa ada $36 \%$ variasi variabel terikat yang dijelaskan oleh faktor lainnya. Gambar 10 menunjukkan ketika elevasi meningkat, suhu juga meningkat sekitar $3^{\circ} \mathrm{C}$. Ketika elevasi menurun, suhu berkurang sekitar $2^{\circ} \mathrm{C}$. 


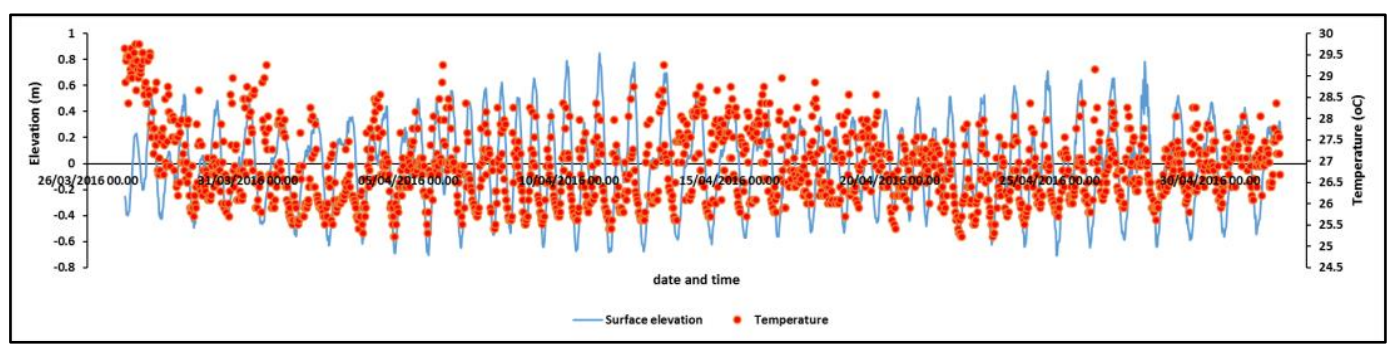

Gambar 9. Flutuasi pasang surut-temperatur pada lokasi KALP

Figure 9. The tide-temperature fluctuation in the largest SGD spot

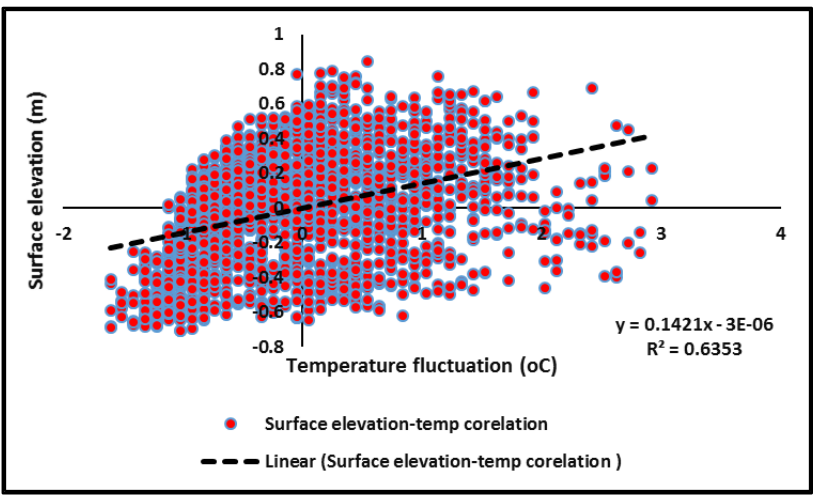

Gambar 10. Korelasi elevasi permukaan dan suhu selama 1 bulan pengukuran

Figure 10. Surface elevation and temperature correlation for 1-month measurement

\section{Pembahasan}

\section{Pengaruh hidrodinamika terhadap sebaran suhu di area KALP}

Pergerakan arus dipermukaan memiliki arah dominan yang sama tetapi arus bergerak lebih dinamis (Gambar 3) yang disebabkan oleh arus sejajar pantai dan arus pasang surut dekat permukaan. Menurut Dijkstra (2008), arus permukaan dipengaruhi oleh pasang surut, gelombang, angin, dan densitas lokal, yang memicu terjadinya perpindahan massa air.

Pada kondisi menuju pasang tinggi, semakin sedikit pengangkutan air tanah bersuhu rendah sehingga terjadi dominasi suhu rendah di titik KALP. Pada saat perpindahan pasang menuju surut, kecepatan arus berkisar 0-0,3 $\mathrm{cm} /$ detik dan dominan bergerak ke arah timur dan timur laut. Selama kondisi ini, kecepatan arus lebih tinggi. Fase pergantian elevasi pasang surut diikuti oleh pelepasan energi pasang surut yang mempengaruhi peningkatan kecepatan arus selama kondisi surut (Wisha et al., 2016). Perairan dangkal di daerah penelitian juga memiliki peran signifikan dalam karakteristik hidrodinamika yang terbentuk dan mengendalikan kecepatan distribusi di sepanjang pantai.

Kecepatan arus akan meningkat pada kondisi surut yang secara signifikan memicu pengangkutan air tawar dengan suhu rendah disekitar lokasi KALP. Distribusi suhu di sekitar KALP dapat memicu ketidakseimbangan lingkungan karena perubahan suhu yang ekstrim. Air dingin yang muncul kemudian bercampur dengan air laut, dapat menurunkan suhu, salinitas, dan densitas secara signifikan.

\section{Dampak keberadaan KALP dengan suhu rendah ke lingkungan sekitar}

Peningkatan elevasi permukaan diikuti oleh fluktuasi suhu. Air dingin dari KALP sangat mendominasi perairan ketika level air menurun. Kondisi ini dapat membahayakan biota laut di sekitar situs KALP seperti karang dan ikan karang. Di sisi lain, ada beberapa biota yang dapat bertahan hidup dan beradaptasi dengan kondisi tersebut.

KALP di Desa Krakas ini adalah debit terbesar yang ditemukan di kedalaman 9-m. Perairan dangkal di area KALP mendukung air tanah bersuhu rendah terdistribusikan dengan baik ke sekitarnya. Faktor utama yang mengangkut keluaran air dingin adalah arus permukaan. Mekanisme transportasi menyebabkan transportasi keluaran air tawar, itu terjadi tergantung pada dinamika massa air. Distribusi keluaran air tanah yang tidak stabil mempengaruhi kondisi sekitarnya menjadi tidak stabil dan mengganggu kemampuan bertahan hidup biota disekitarnya. Menurut Beck et al., (2007), besarnya keluaran air tanah bawah laut bervariasi secara musiman.

Air dingin yang keluar bersamaan dengan salinitas rendah memiliki peran penting dalam memicu perubahan lingkungan. Dampak ini tidak hanya disebabkan oleh keberadaan KALP tetapi juga oleh faktor-faktor iklim seperti El-Nino Southern Oscillation (ENSO) yang berpengaruh terhadap anomali suhu perairan secara global dan regional karena lokasi Selat Lombok adalah salah satu gerbang Arus Lintas Indonesia (ARLINDO). Signifikansi ekologis musiman dan pelepasan air tanah di bawah laut dapat memicu kematian karang (Costa et al., 2017). Variasi suhu permukaan laut antar laut dari Selat Lombok 
secara nyata memperkuat terjadinya peristiwa pendinginan yang jauh lebih kuat yang sangat mendorong adaptasi biota laut (Song et al., 2007).

\section{Kesimpulan dan Saran}

Distribusi KALP dipengaruhi oleh faktor hidrodinamika secara vertikal dan horizontal. Mekanisme Ekman pumping memiliki peran mengendalikan distribusi vertikal KALP. Fluktuasi suhu mengikuti perubahan elevasi permukaan. Sehingga jelas mengapa distribusi anomali temperatur dikendalikan oleh arus pasang surut. Munculnya KALP dapat memicu adaptasi biota di daerah sekitarnya.

\section{Persantunan}

Ucapan terima kasih diberikan kepada Loka Riset Sumber Daya dan Kerentanan Pesisir (LRSDKP) untuk anggaran penelitian DIPA 2016 di Lombok Utara dan untuk semua orang yang membantu dalam penyelesaian artikel ini.

\section{Daftar Pustaka}

Bakti, H., Lubis, R., Delinom, R., \& Naily, W. (2012). Identify on submarine ground water discharge (SGD) on the alluvial coast of North Lombok, West Nusa Tenggara. Jurnal Lingkungan Dan Bencana Geologi, 3(2), 133-149.

Beck, A. J., Rapaglia, J. P., Cochran, J. K., \& Bokuniewicz, H. J. (2007). Radium massbalance in Jamaica Bay, NY: Evidence for a substantial flux of submarine groundwater. Marine Chemistry, 106(3-4), 419-441. https://doi.org/10.1016/j.marchem.2007.03.0 08

Boehm, A. B., Sanders, B. F., \& Winant, C. D. (2002). Cross-shelf transport at Huntington Beach. Implications for the fate of sewage discharged through an offshore ocean outfall. Environmental Science and Technology, 36(9), 1899-1906. https://doi.org/10.1021/es0111986

Costa, M. B., Macedo, E. C., Valle-Levinson, A., \& Siegle, E. (2017). Wave and tidal flushing in a near-equatorial mesotidal atoll. Coral Reefs. https://doi.org/10.1007/s00338-016$1525-\mathrm{x}$

Dijkstra, H. A. (2008). Dynamical oceanography. Dynamical Oceanography. https://doi.org/10.1007/978-3-540-76376-5

Johan, O., Kusumah, G., \& Wisha, U. J. (2018). Kondisi Terumbu Karang di kawasan KALP Pantai Krakas, Lombok Utara. Jurnal
Segara, 13(3), 193-200.

https://doi.org/10.15578/segara.v13i3.6548

Lestiana, H., Sukristiyanti, S., Bakti, H., \& Lubis, R. F. (2017). Pemanfaatan Band Termal Citra Landsat Untuk Identifikasi Keluaran Airtanah Lepas Pantai (KALP) di Pantai Utara Lombok. RISET Geologi Dan Pertambangan, 27(1), 65-75. https://doi.org/10.14203/risetgeotam2017.v2 7.422

Lubis, R. F., Bakti, H., \& Suriadarma, A. (2011). Submarine Gdroundwater Discharge ( SGD ) In Indonesia. Jurnal Riset Dan Geologi Pertambangan, 21(1), 57-62. https://doi.org/https://doi.org/10.14203/riset geotam2011.v21.46

Mehdiabadi, F. E., Mehdizadeh, M. M., \& Rahbani, M. (2015). Simulating Wind Driven Waves in the Strait of Hormuz using MIKE21 (Simulasi Gelombang Angin di Selat Hormuz Menggunakan MIKE21). ILMU KELAUTAN: Indonesian Journal of Marine Sciences, 20(1), 1. https://doi.org/10.14710/ik.ijms.20.1.1-8

Moore, W. S. (2010). The Effect of Submarine Groundwater Discharge on the Ocean. Annual Review of Marine Science. https://doi.org/10.1146/annurev-marine120308-081019

Ningsih, N. S., Rachmayani, R., Hadi, S., \& Brodjonegoro, I. S. (2018). Internal Waves Dynamics in the Lombok Strait Studied By a Numerical Model. International Journal of Remote Sensing and Earth Sciences (IJReSES), 5(1), 17-33. https://doi.org/10.30536/j.ijreses.2008.v5.a1 226

Oktavia, R., Pariwono, J., \& Manurung, P. (2011). Variasi muka laut dan arus geostrofik permukaan perairan selat Sunda berdasarkan data pasut dan angin tahun 2008. Jurnal Ilmu Dan Teknologi Kelautan Tropis, 3(2), 127-152.

https://doi.org/https://doi.org/10.29244/jitkt. v3i2.7827

Rachmayani, R., Atma, G., Suprijo, T., \& Sari, N. (2006). Marine Current Potential Energy for Environmental Friendly Electricity Generation in Bali, Lombok and Makassar Straits. In Environmental Technology and Management Conference, September 7-8, 2006.

Song, Q., Vecchi, G. A., \& Rosati, A. J. (2007). The role of the Indonesian throughflow in the Indo-Pacific climate variability in the GFDL coupled climate model. Journal of Climate. https://doi.org/10.1175/JCLI4133.1 
Thompson, C., Smith, L., \& Maji, R. (2007). Hydrogeological modeling of submarine groundwater discharge on the continental shelf of Louisiana. Journal of Geophysical Research: Oceans, 112(C03014), 1-13. https://doi.org/10.1029/2006JC003557

Warren, I. R., \& Bach, H. K. (1992). MIKE 21: a modelling system for estuaries, coastal waters and seas. Environmental Software, 7(4), 229-240. https://doi.org/10.1016/02669838(92)90006-P

Wisha, U. J., Husrin, S., \& Prasetyo, G. S. (2016). Hydrodynamics of Bontang Seawaters: Its Effects on the Distribution of Water Quality Parameters. Indonesian Journal of Marine Sciences, 21(2), 123-134. https://doi.org/https://doi.org/10.14710/ik.ij ms.21.3.123-134

Wisha, U. J., Husrin, S., \& Prihantono, J. (2015). Hidrodinamika Perairan Teluk Banten Pada Musim Peralihan (Agustus-September). ILMU KELAUTAN: Indonesian Journal of Marine Sciences, 20(2), 101-112. https://doi.org/10.14710/ik.ijms.20.2.101112 